\title{
Upper gastrointestinal tract Crohn's disease
}

\author{
HUGHJ FREEMAN, MD
}

\begin{abstract}
Crohn's disease may involve any site within the gastrointestinal tract. Usually pathology is present in the ileum and/or colon, but atypical presentations may occur with apparently isolated' involvement of the oropharynx, esophagus or gastroduodenum. If changes typical of Crohn's disease are detected in the upper gastrointestinal tract, then a careful assessment is required involving radiographic, endoscopic and histologic studies to determine if pathology is present in more distal intestine. In addition, microbiologic studies may be important to exclude infectious causes, especially of granulomas. If these studies are negative, prolonge 1 follow-up may be required to establish a diagnosis of Crohn's disease. Although upper gastrointestinal involvement is increasingly recognized as a significant cause of morbidity in Crohn's disease, the treatment options are limited, largely anecdotal and need to be the subject of detailed epidemiologic investigation and clinical trials. Can J Gastroenterol 1990;4(1):26-32
\end{abstract}

Key Words: Crohn's disease, Inflammatory bowel disease, Gastrocolic fistula, Granulomatous gastritis, Yersinia enterocolitica

\section{Maladie de Crohn des voies digestives supérieures}

RESUME: La maladie de Crohn peut être localisée à un niveau quelconque du tube digestif. Habituellement, elle affecte l'iléon et/ou le côlon mais elle peut se manifester de façon atypique et atteindre l'oropharynx, l'esophage ou le gastroduodénum. Si certains changements attribuables à la maladie de Crohn sont décelés dans la voie digestive supérieure, il faut alors procéder à une évaluation soigneuse comprenant des examens radiographiques, endoscopiques et histologiques destinés à déterminer si la maladie s'est propagée à d'autres segments de l'intestin. De plus, il peut être important de procéder à des examens microbiologiques afin d'exclure les origines infectieuses - dans le cas des granulomes surtout. Si les résultats sont négatifs, un suivi prolongé peut être nécessaire avant que le diagnostic définitif de maladie de Crohn ne soit posé. Bien que la participation de la voie digestive supérieure soit de plus en plus reconnue comme une cause importante de morbidité dans la maladie de Crohn, les options de traitement sont limitées et largement anecdotiques. Elles mériteraient de faire l'objet d'investigations épidémiologiques détaillées et d'essais cliniques.

Department of Medicine (Gastroenterology), University Hospital; and University of British Columbia, Vancouver, British Columbia

Correspondence and reprints: Dr Hugh Freeman, Head, Gastroenterology, ACU F-137.

University Hospital, University of British Columbia, 2211 Wesbrook Mall, Vancouver, British

Columbia V6T IW5. Telephone (604) 228-7216 or 7235

Received for publication June 19, 1989. Accepted September 19, 1989
A NY SITE WITHIN THE GASTROINTEST. inal tract may be involved in Crohn's disease (1). It is well recognized that ileal and/or colonic involvement are most often present, but occasionally 'isolated' disease localized to one or more sites in the upper gastrointestinal tract occurs. Indeed, if involvement with Crohn's disease is defined by the presence of subtle endoscopic changes including aphthoid ulcerations or histologic features alone, the stomach and duodenum appear to be relatively common sites of Crohn's disease. Changes in the esophagus have also been recorded but appear to be less frequent. If 'isolated' granulomatous disease is documented, however, careful ex. clusion of other causes of granuloma is required. Generally, this should include an evaluation of the distal small and large bowel to determine if the more typical radiographic, endoscopic or histologic features of Crohn's disease are present.

\section{GASTRODUODENAL DISEASE}

Frequency: Some of the earliest reports recognizing gastric involvement in Crohn's disease were recorded by Ross (2) in 1949 and Comfort et al (3) in 1950. Since then, well over 100 patients have heen reported with granulomatous inammatory disease of the stomach and duodenum attributed to Crohn's disease. As the majority of these reports have focused largely on clinically significant involvement, estimated to be approximately 2 to $4 \%$ of all patients (4), the true 
frequency is likely to be much higher. Indeed, initial reports suggested that the prevalence of patients with documented Crohn's disease elsewhere in the gastrointestinal tract was no more than $7 \%$ (5-7). Subsequent studies, however, indicate that disease was present in the upper gastrointestinal tract in over $20 \%$ $(8,9)$. This reflects, in part, an increased appreciation in recent years for the widespread, often segmental or focal nature of this inflammatory process within the gastrointestinal tract. Moreover, the combined use of upper endoscopy and mucosal biopsy has increased the incidence of recognition, even if the disease is clinically or radiographically 'silent' at this site. Clinical features: In many patients, symptoms relating to the upper gastrointestinal tract may be limited or frequently overshadowed by diarrhea and other symptoms associated with small or large intestinal disease. Even significant symptoms relating to resistant ulceration and progessive gastroduodenal stenosis may go unrecognized until later in the dinical course. In this setting, marked nutritional disturbance and weight loss are corvimon, in part reflecting the progressive impairment of food intake and impaired gastric emptying of nutrients into the small intestine. In some patients, the clinical features of anorexia nervosa may be present $(10,11)$. Symptoms related to gastric outlet obstruction such as nausea and vomiting may result. Because of the cicatrizing nature of this inflammatory process in the antral and pyloric region, the proximal stomach may appear dilated with retained food debris and sometimes bezoar formation. Hemorrhage, especially from deep ulceration, has been possibly incorrectly considered an uncommon presentation for most granulomatous gastric disorders (12); in part, this idea may reflect a tendency to attribute the cause of ulceration to 'acid peptic' disease or commonly prescribed analgesics used to manage abdominal pain or arthropathy. In addition, endoscopic biopsy, especially in this setting, is commonly not done since patients are usually young so that distinction from neoplastic disease is rarely difficult. If ulcers or erosions are present, however, endoscopic biopsy may reveal granulomas and other more typical his- tological features of Crohn's disease. In addition to blood loss, however, anemia may result from deficits of iron or folic acid due in part to reduced absorption from a diseased proximal small intestine. 'Isolated' gastric disease: In some patients, gastric involvement alone may occur $(13,18)$. In these patients, pain may be a prominent symptom and although no obstruction is evident, abnormal gastric emptying may still occur. Diagnosis may be suggested by nuclear scans or by barium studies showing impaired emptying of contrast; in the most extreme situations, a poorly distensible gastric antrum, sometimes with aphthoid ulceration and 'cobblestoning' of antral folds with fissuring, ulceration and pyloric deformity may be present. In one report, the barium radiographic 'ram's horn' sign was described (19). In these patients. Crohn's disease may later become evident in the more distal small and large intestine.

'Isolated' duodenal disease: Isolated involvement of the proximal small intestine including the duodenum may also occur (20-24). Most often evidence of such involvement is limited to focal inflammatory changes or isolated mucosal granulomas, with multinucleated giant cells or loose aggregates and clusters of epithelioid cells. In others, more severe changes may be present with multiple and diffuse stenotic small bowel segments. Such patients are prone to episodes of bowel obstruction, generalized malnutrition and numerous specific nutrient deficiencies. The frequency of more clinically significant, extensive small bowel disease is not known. In one early study (25), based largely on contrast radiographic examinations, 18 of 330 patients with Crohn's disease seen from 1944 to 1970 were described as having more than diffuse jejunal involvement. The early literature on Crohn's disease (26-28) also describes the laparotomy appearances of the small intestine in rare patients characterized by diffuse and multiple miliary-like granulomatous serosal lesions; the proximal small bowel was also involved. In these patients, microbiologic studies, specifically for Mycobacterium tuberculosis were negative. This entity was termed 'miliary Crohn's disease'; it was suggested that this entity may represent an early stage of the disease.

In patients with duodenal disease, a concomitant inflammatory change in the pancreas or biliary tract may be present. In this setting, biliary tract stones or sludge, as well as the reflux of duodenal content into the pancreatic duct through an incompetent ampulla, have been described (29-31). In others, drug induced disease of the pancreas has been reported, especially with sulfasalazine (32). metronidazole (33) and immunosuppressive agents, including azathioprine and 6-mercaptopurine (34-36). Alcohol associated injury can also occur in these patients. More recently, direct ampullary involvement with stenosis as well as common bile duct obstruction have been recorded (37). In addition, duodenal bezoar formation (38), and fistulous communication with the pancreatic duct have been described (39).

Endoscopic features: Endoscopy may permit a better appreciation of the changes associated with Crohn's disease in the upper gastrointestinal tract, even if it is apparently asymptomatic $(8,40-45)$. Gastric and duodenal ulceration, especially linear or serpiginous, may be observed. The antrum may be poorly distensible with air insufflation, and rigid pyloric or pyloroduodenal stenosis may prohibit passage of even 'pediatriccalibre' endoscopes. Macroscopic changes may also include a minimal colour alteration, either patchy or diffuse, focal white nodules, aphthoid ulceration or erosion with exudate and apparent mucosal 'cobblestoning'. Strictures and fistulae from the stomach or duodenum into nearby intestinal loops or the pancreatobiliary tract may be appreciated. More often, with the development of fistulae, a coexistent inflammatory focus is present in an adjacent loop of small or large bowel - in this setting, the fistula is usually considered 'secondary' to the intestinal disease (46-54). Often, upper endoscopy is limited in its ability to determine the fistula opening which usually appears only as a small, sometimes erythematous, raised dimple with exudate on a raised cluster of gastric folds (55). The most common site for a fistula recognized at endoscopy is the greater curvature of the stomach, usually from the 
splenic flexure of the colon. In patients with a prior ileocolonic resection, however, fistulous communication between the anastomosis and the descending duodenum may be seen. Routine barium or gastrograffin contrast studies remain the most useful for diagnosis, although contrast introduced directly through an endoscopic catheter may also be used. Although a gastrocolic fistula is most common (49-53), other causes of fistula should also be considered by the endoscopist in patients with Crohn's disease, including carcinoma of the colon and stomach as well as lymphoma (56).

Histologic features: Biopsies from normal appearing or grossly abnormal gastric mucosa often reveal nonspecific inflammatory changes; focal neutrophilic infiltrates and multinucleated giant cells or epithelioid cell clusters may also be seen, and may be more suggestive of possible Crohn's disease. The detection of granulomas is not specific for Crohn's disease, especially if disease is not apparent elsewhere in the intestinal tract. However, their initial detection in a patient not known to have Crohn's disease should lead to endoscopic and radiographic assessments of the small and large bowel. Histological distinction of the granulomata from other entities, including sarcoidosis, is often not possible with 'isolated' gastric involvement, and diagnosis may be established only after further investigations including pulmonary assessment, liver and possibly lymph node biopsy (57-60). In addition, other entities should be excluded in the presence of 'isolated' gastric disease, such as foreign bodies (eg, suture-associated), tuberculosis, histoplasmosis and syphilitic gastric involvement as well as other infectious causes (59-61). Distinction from gastric neoplastic disease, although it is not apparently increased in Crohn's disease, is important. In the pediatric patient, chronic granulomatous disease may be a special consideration, especially if gastric outlet obstruction is present (62). The syndrome of necrotizing granulomatous gastritis seems sufficiently distinct from the pathological changes in Crohn's disease such that differentiation is not usually difficult (63). If endoscopic or suction biopsies of the duodenum or proximal jejunum reveal 'isolated' gran- ulomas, exclusion of other causes is warranted, particularly for infectious disorders, as their detection may alter therapy (61). In the absence of granulomas, Crohn's disease may still be present, especially if a constellation of acute, particularly focal, neutrophilic inflammatory changes or crypt abscesses are present (45). In occasional patients, small bowel biopsies may reveal changes more typi$\mathrm{cal}$ of celiac sprue with mucosal villus atrophy and crypt hyperplasia (45). These mucosal biopsy changes may be patchy or diffuse and variable in the degree of severity ranging from mild to severe (64). Variable changes may be appreciated only if multiple small bowel sites are biopsied. A number of reports have recorded the coexistence of celiac sprue and inflammatory bowel disease in the same patients (65); some likely represent Crohn's disease alone. Differentiation of Crohn's from celiac sprue may be especially difficult in some patients, particularly if Crohn's disease is not readily evident in the more distal small or large bowel; moreover, disorders characterized by spontaneous remissions may be difficult to distinguish even with clinical improvement on a gluten-free diet. While there are other causes of a 'flat' small intestinal biopsy (64), the acute nature of the inflammatory process with polymorphonuclear leukocytes and crypt abscesses may favour a diagnosis of Crohn's disease (45). In addition, other entities should be considered if an acute inflammatory process is present without granulomas, including Zollinger-Ellison syndrome (66) and so-called 'benign nongranulomatous jejunitis', an entity also associated with celiac sprue (67). Infectious agents, especially if they are common in a specific geographic area, deserve careful exclusion. In the authors' institution, for example, a commonly recognized agent in patients with gastrointestinal disease is Yersinia enterocolitica; in the authors' studies, endoscopic and histologic changes in the upper gastrointestinal tract have been frequent (68). Finally, the possibility of lymphoma in the proximal small intestine must be considered; this distinction may be especially difficult because of the frequent presence of ulcerated and inflamed small intestine in lymphoma and the focal nature of the lymphomatous infiltrates in some patients (69-72).

\section{OROPHARYNGEAL AND ESOPHAGEAL DISEASE}

Crohn's disease occasionally involves the mucous membranes of the oropharynx and esophagus. Rarely, the respiratory tract may be involved, distinct from sarcoidosis or infectious disorders such as tuberculosis (58-60). Granulomatous inflammation of the minor salivary gland ducts may also occur, causing sublingual cystic lesions due to duct rupture and mucocele formation (73). Usually, involvement of the oropharynx or esoph. agus occurs in conjunction with evidence of disease elsewhere, particularly ileocolonic or perianal disease. Often the symptoms are minimal but some patients may complain of painful oral ulcers, or frequently dysphagia or odynophagia. Sometimes these symptoms predominate over bowel symptoms and result in reduced food intake, malnutrition and weight loss.

Oral lesions in Crohn's disease were first reported in 1969 (74), with isolated disease of the mouth in 1972 (75). In the oropharynx, superficial or epithelial ulceration is relatively frequent (at least $10 \%$ ) compared to the less common changes of painful swelling and ulceration of the buccal mucosa, as well as the erythematous gingival hyperplasia associated with histologically documented granulomatous inflammatory disease (less than 1\%). Other described changes include angular cheilitis, mucosal tags or cobblestoning of the oral mucosa and hyperplastic gingival lesions (76-79). Finally, the changes associated with nutrient deficiency and the effects of medications, including the StevensJohnson syndrome, may occur.

In some patients, the pathology may be limited to this site or be the initial clinical manifestation years before the disease is detected elsewhere in the gastrointestinal tract $(80,81)$. In such patients, consideration should be given to such entities as Behcet's syndrome if other clinical features of this disorder are present, such as genital ulceration. In addition, microbiological causes of oral ulceration require exclusion, notably $Y$ enterocolitica, an infectious agent that has been associated with a clinical syndrome of 
ileocolitis similar to Crohn's disease (68). The pathogenesis of the oral lesions in Crohn's disease remains unknown. Reduced salivary $\operatorname{IgA}$ secretion (77) has been postulated to result in impaired mucosal defence against one or more infectious agents. Recently, microbiological studies of the periodontal flora of patients with inflammatory bowel disease have revealed unusual microorganisms consistent with the genus Wolinella; extracts and culture supernatants of these motile Gram-negative rods have revealed a serum mediated defect in neutrophil chemotaxis having a possible role in the disease pathogenesis (82).

In the esophagus, isolated involvement has been described but appears to be rare. In this setting, the extension of granulomatous processes from the respiratory tract and mediastinum must be excluded. Franklin and Taylor (83) first described isolated esophageal stricture and granulomatous esophagitis in three patients in 1950. Esophageal disease with Crohn's disease involving other sites in the gastrointestinal tract was first recorded in 1954 (84). Another patient was described by Achenbach et al (85), in 1956 as having stenosis, multiple perforations and mediastinal abscesses. Interestingly, this patient also had perineal disease, erythema nodosum, pyoderma gangrenosum, arthritis and hepatic dysfunction that resolved with esophagectomy. Later, additional patients were recorded in 1968 and $1969(86,87)$, while the first documentation of noncaseating esophageal granuloma was noted in 1973 (5). A granulomatous histologic change of the esophagus was also documented using endoscopic biopsy in a patient with Crohn's colitis in 1977 (88). One year later, Crohn's disease of the esophagus was also associated with Barrett's esophagus in a patient with ileal involvement (89). Although esophageal involvement was previously thought to occur mainly in older patients with Crohn's disease (90), a more recent retrospective survey of 500 patients followed over a three year period in Belgium revealed nine patients with esophageal involvement having a mean age at diagnosis of 21 years (range 15 to 44 ) (91). In most, extraintestinal manifestations, especially arthritis and genital ulceration, were common, and a history of tuberculostatic or antiherpetic therapy was frequent.

Some of the earlier cases of esophageal Crohn's disease were treated surgically because of severe obstructive symptoms or suspicion of neoplastic disease. Later, lower esophageal strictures (5), as well as cricopharyngeal Crohn's disease (92), were reported to have been successfully managed with stricture dilatation.

Extension of Crohn's disease into the respiratory tract has also been well documented (93). This may not be too surprising given the common developmental origins of the gastrointestinal and respiratory tracts and the recent evidence that the immune system of the gastrointestinal tract is common to all mucosal surfaces (94). Upper airway obstruction and laryngeal involvement with granulomatous inflammation have been described $(95,96)$, as well as bronchial granulomas (97), suppuration and bronchiectasis (98), noncaseating granulomatous pulmonary infiltrates $(99,100)$, and sulfasalazine associated pneumonitis (101105). Subclinical lung function abnormalities have also been noted, including abnormal pulmonary function tests (106-108), impaired carbon monoxide diffusion (109), and a high incidence of latent lymphocytic alveolitis defined by bronchoalveolar lavage (110).

\section{TREATMENT}

The role of most treatment regimens in Crohn's disease of the esophagus, stomach and proximal bowel is not known. Most patients with oral lesions require no specific oral treatment, although some find mild analgesics or Orabase (Squibb; a mixture of gelatin, pectin, sodium carboxymethylcellulose in a mineral oil base) useful. Others find antacids helpful. Cheilitis and other more significant lesions have been treated with a combination of systemic steroids, sulfasalazine, metronidazole and azathioprine but their effectiveness is not obvious. Local intralesional steroids have also been recommended (81).

For gastroduodenal involvement of Crohn's with stenosis, patients may respond to medical treatment with corticosteroids and parenteral nutrition (110), and possibly, measures (eg, ranitidine) directed toward the control of acid secretion (4). In a recent preliminary re- port, omeprazole appeared to provide symptomatic benefit in certain patients treated previously with ranitidine (111) Impaired gastric emptying in Crohn's disease may result in the development of nutritional deficits, growth failure in children and impaired delivery of medications to the small and large intestine (112). Gastric retention of enteric coated sulfasalazine tablets has been noted (113). and similar difficulties are likely to result from other such medications administered in the treatment of Crohn's disease or its extraintestinal manifestations (eg, arthritis). This may be an important consideration in clinical trials designed to assess the efficacy of a specific treatment modality, including disease apparently localized to the more distal small or large intestine. Recently, some consideration has been afforded to the newer er : eric liquid formulations of 5-aminosalicylic acid (114). Parenteral nutrition may be used, but it is unlikely to resolve the disease process or alter its natural history, particularly if fibrotic inflammatory gastroduodenal disease is already present. Since these patients may be nutritionally depleted with significant weight loss, parenteral nutrition, especially prior to surgical intervention, may be essential for resuscitation.

If obstructive symptoms are due to gastroduodenal stenosis, a bypass gastroenterostomy has generally been recommended $(42,115,116)$. In this setting, the role of vagotomy has not been established and may not offer any significant advantage over continuing pharmacologic treatment to suppress acid secretion. If a surgical approach is selected, however, worsening diarrhea may result, especially if the intestine is already shortened from previous resections. Moreover, the presence of a fistula, particularly a duodenal fistula, is not a definitive indication for early surgical intervention $(49,54)$. Repair of fistula, however, can usually be accomplished in most patients with excision and primary closure, although occasionally a two-stage repair is necessary (49).

\section{CONCLUSION}

Crohn's disease involving the upper gastrointestinal tract may be a significant clinical problem in some patients with 
disease elsewhere in the small and large intestine. In occasional patients, disease may appear 'isolated' and initially involve only the upper gastrointestinal tract. In this setting, a careful assessment should be done to define if the disease is present

\section{REFERENCES}

1. Freeman HJ. Definition of inflammatory bowel disease In: Freeman HJ, ed. Inflammatory Bowel Disease, vol 1. Boca Raton: CRC Press, 1989:3-7.

2. Ross JR. Cicatrizing enteritis, colitis and gastritis. Gastroenterology 1949:13:344-50.

3. Comfort MW, Weber HM, Baggenstoss AH, Kiely WF. Nonspecified granulomatous inflammation of the stomach and duodenum. Its relation to regional enteritis. Am J Med Sci 1950;220:616-32

4. Dobbins WO. Gastroduodenal Crohn's disease. In: Bayless TM, ed. Current Management of Inflammatory Bowel Disease. Philadelphia: BC Decker, 1989:218-20.

5. Haggitt RC, Meissner WA. Crohn's disease of the upper gastrointestinal tract. Am J Clin Pathol 1973;59:613-22

6. Fielding JF, Toye DKM, Beeton DC, Cooke WT. Crohn's disease of the stomach and duodenum. Gut 1970; 11:1001-6,

7. Nugent FW, Richmond M, Park SK Crohn's disease of the duodenum. Gut 1977;18:115-20,

8. Korelitz BI, Waye JD, Kruening J, et al. Crohn's disease in endoscopic biopsies of the gastric antrum and duodenum. Am J Gastroenterol 1981;76:103-9.

9. Goldberg HI, Coruthers SB, Nelson JA, Singleton JW. Radiographic findings of the National Cooperative Crohn's Disease Study, Gastroenterology 1979; 77:925-37.

10. Jenkins AP, Treasure J, Thompson RPH. Crohn's disease presenting as anorexia nervosa. Br Med J 1988;296:699-70.

11. Benjamin S. Crohn's disease presenting as anorexia nervosa. $\mathrm{Br} \mathrm{Med} \mathrm{J}$ 1988;296:1005

12. Fung WP, Foo KT, Lee YS. Gastric sarcoidosis presenting with hematemesis. Med J Aust 1975;2:47-9.

13. Talseth $T$. Isolated gastric involvement in Crohn's disease. Acta Chir Scand 1976;142:611-3.

14. Khan MH, Lam R, Tamoney HJ. Isolated granulomatous gastritis. Am J Gastroenterol 1979;71:90-4.

15. Baudin D, DaCosta LR, Prentice RSA, Beck IT. Crohn's disease of the stomach: Case report and review of literature. Dig Dis Sci 1973;18:623-9.

16. Fielding JF, Cooke WT. Peptic ulceration in Crohn's disease. Gut 1970;11:998-1000. elsewhere in the intestine and to exclude infectious causes, particularly if granulomas are observed. If these studies are negative, prolonged follow-up may be required to establish a diagnosis. Although upper gastrointestinal involvement is in-

17. Johnson OA, Hoskins DW, Todd J, Thorbjarnarson B. Crohn's disease of the stomach. Gastroenterology 1966; 50:571-7

18. Johnson FW, Delaney JP. Regional enteritis involving stomach. Arch Surg 1972;105:434-7.

19. Farman J, Faegenburg D, Dallemand S, Chen CK. Crohn's disease of the stomach: The 'ram's horn' sign. Am J Roent Rad Ther Nuc Med 1975; 123:242-51.

20. Edwards AM, Mickalyshyn B. Sherbaniuk RW, Costopoulos LB. Regional enteritis of the duodenum: A review and report of five cases. Can Med Assoc J 1965;93:1283-95.

21. Nugent FW, Richmond M, Park SK. Crohn's disease of the duodenum. Gut 1977:18:115-20.

22. Nugent FW, Roy MA. Duodenal Crohn's disease: An analysis of 89 cases. Am J Gastroenterol 1989;84:249-54.

23. Jones GW, Dooley MR, Schoenfield LJ. Regional enteritis with involvement of the duodenum. Gastroenterology 1966;51:1018-22.

24. Frandsen PJ, Jarnum S, Malmstrom J. Crohn's disease of the duodenum. Scand J Gastroenterol 1980;15:683-8.

25. Cooke WT, Swan CJM. Diffuse jejuno-ileitis of Crohn's disease. QJ Med 1974:43:583-601.

26. Heaton KW, McCarthy CF, Horton RE, Cornes JS, Read AE. Miliary Crohn's disease. Gut 1970;8:4-7.

27. Manns Jj. Miliary Crohn's disease. Br Med J 1972:4:152.

28. Otto HF, Gebbers JO, Kugler S. Miliarer morbus Crohn. Deutsche Med Wochen 1975:100:505-7.

29. Legge DA, Hoffman HN, Carlson HC. Pancreatitis as a complication of regional enteritis of the duodenum. Gastroenterology 1971;61:834-7.

30. Altman HS, Phillips G, Bank S, Klotz H. Pancreatitis associated with duodenal Crohn's disease. Am J Gastroenterol 1983;78:174-7.

31. Barthelemy CR. Crohn's disease of the duodenum with spontaneous reflux into the pancreatic duct. Gastrointest Radiol 1983;8:319-20.

32. Block MB, Genant HK, Kirsner JB. Pancreatitis as an adverse reaction to salicylazosulfapyridine. N Engl J Med 1970;282:380-2

33. Plotnick BH, Cohen I, Tsang T. Cullinane T. Metronidazole-induced creasingly recognized as a significant cause of morbidity in some patients with Crohn's disease, the treatment options are limited and largely anecdotal. More focused studies of this concern are clearly warranted.

pancreatitis. Ann Intern Med 1985; 103:891-2.

34. Sturdevant RAL, Singleton JW, Deren JJ, Law DH, McCleery JL. Azathioprine-related pancreatitis in patients with Crohn's disease. Gastroenterology 1979;77:883-6

35. Bank L, Wright JP. 6-Mercaptopurinerelated pancreatitis in 2 patients with inflammatory bowel disease. Dig Dis Sci 1984;29:357-9.

36. Haber CJ, Meltzer SJ, Present DH, Korelitz BI. Nature and course of pancreatitis caused by 6-mercaptopurine in the treatment of inflammatory bowel disease. Gastroenterology 1986;91:982-6.

37. Foutch PG, Ferguson DR. Duodenal Crohn's disease complicated by common bile duct obstruction: Report of a case and review of the literature. Am J Gastroenterol 1984:79:520-4.

38. Eliakim R, Fich A, Libson E, Katz E Rachmilewitz D. Crohn's disease of the duodenum presented as pancreatitis due to persimmon bezoar. J Clin Gastroenterol 1987:9:553-5.

39. Halparin LS, Simmonds SD, Pitman R, McCann L. Duodenal-pancreatic fistula accompanying Crohn's disease of the distal duodenum. Am J Gastroenterol. (In press)

40. Danzi JT, Farmer RG, Sullivan BH, Rankin GB. Endoscopic features of gastroduodenal Crohn's disease. Gastroenterology 1976;70:9-13.

41. Brown KM, Kass M, Wilson R. Isolated granulomatous gastritis. Treatment with corticosteroids. J Clin Gastroenterol 1987:9:442-6.

42. Hermos JA, Cooper HL, Kramer P. Trier JS. Histological diagnosis by peroral biopsy of Crohn's disease of the proximal intestine. Gastroenterology 1970;59:868-73.

43. Haner WV, Goldstein F, Wirto CW. Granulomas in suction biopsies of distal duodenum. Gastroenterology 1970; 59:862-7.

44. Rutgeerts P, Onette F, Vantrappen G, Geboes K, Brockaert L, Talloen L. Crohn's disease of the stomach and duodenum: A clinical study with emphasis on the value of endoscopy and endoscopic biopsies. Endoscopy 1980;12:288-94.

45. Schuffler MD, Chaffee RG. Small intestinal biopsy in a patient with Crohn's disease of the duodenum. The spectrum of abnormal findings 
in the absence of granulomas.

Gastroenterology 1979;76:1009-14.

46. Korelitz BI. Colonic-duodenal fistula in Crohn's disease. Dig Dis Sci 1977; 22:1040-8,

47. Leichtling JJ, Garlock HJ. Granulomatous colitis complicated by gastrocolic, duodenocolic and colopulmonic fistulas. Gastroenterology 1962;43:151-65.

48. Goldwasser B, Mazor A, Wiznitzer T. Enteroduodenal fistulas in Crohn's disease. Dis Colon Rectum 1981; 24:485-6.

49. Jacobson IM, Schapiro RH, Warshaw AL. Gastric and duodenal fistulas in Crohn's disease Gastroenterology 1985;89:1347-52.

50. McDaniel NT, Bluth El, Ray JE. Gastrocolic fistula in Crohn's disease. Am J Gastroenterol 1982;77:588-9.

51. Kokol W. Pickleman J, Steinberg JJ, Banich FE. Gastrocolic fistula in Crohn's disease. Surg Gynecol Obstet 1978; 146:701-4.

52. Metzger WH, Ranganath KA. Crohn's disease presenting as a gastrocolic fistula. Am J Gastroenterol 1976; 65:258-61.

53. Logio T, Chaiken B, Roth J, Newman E, Siegal T. The management of Crohn's colitis with colonogastric fistula. Dis Colon Rectum 1987;30;699-704.

54. Klein S, Greenstein AJ, Sachar DB. Disdenal fistulas in Crohn's disease. J Clin Gastroenterol 1987;9:46-9.

55. Haber GB. Role of endoscopy in inflammatory bowel disease. Dig Dis Sci 1987;32:16S-25S.

56. Kini SU, Pai PK, Rao PK, Kini AU. Primary gastric lymphoma associated with Crohn's disease of the stomach. Am J Gastroenterol 1986;81:23-5.

57. Daniele RP, Dauber JH, Rossman MD. Immunologic abnormalities in sarcoidosis. Ann Intern Med 1980;92:406-16.

58. Sprague R, Harper P, McClain S, Trainer T, Beeken W. Disseminated gastrointestinal sarcoidosis. Gastroenterology 1984;87:421-5.

59. Chinitz MA, Brandt LJ, Frank MS, Frager D, Sablay L. Symptomatic sarcoidosis of the stomach. Dig Dis Sci 1985;30:682-8.

60. Bulger K, O'Riordan M, Purdy S, O'Brien M, Lennon J. Gastrointestinal sarcoidosis resembling Crohn's disease. Am J Gastroenterol 1988;83:1415-7.

61. Present DH, Lindner AE, Janowitz HD. Granulomatous disease of the gastrointestinal tract. Annu Rev Med 1966; 17:243-56

62. Johnson FE, Humbert JR, Kuzela DC, Todd JK, Lilly JR. Gastric outlet obstruction due to X-linked chronic granulomatous disease. Surgery 1975; $78: 217-23$

63. Compton CC, Von Lichtenberg F. Necrotizing granulomatous gastritis and gastric perforation of unknown etiology: A first case report. J Clin Gastroenterol 1983:5:59-65.

64. Perera DR, Weinstein WM, Rubin CE. Small intestinal biopsy. Hum Pathol 1975;6:157-217.

65. Gilberg R, Dotevall G, Ahren C. Chronic inflammatory bowel disease in patients with celiac sprue. Scand J Gastroenterol 1982:17:491-6.

66. Shimoda SS, Saunders DR, Rubin CE. The Zollinger-Ellison syndrome with steatorrhea. II. The mechanisms of fat and vitamin $\mathrm{B} 12$ absorption. Gastroenterology 1968;55:705-23.

67. Jeffries $G H$, Steinberg $G H$, Sleisenger $\mathrm{MH}$. Chronic ulcerative (nongranulomatous) jejunitis. Am J Med 1968:44:47-59.

68. Simmonds SD, Noble MA, Freeman HJ. Gastrointestinal features of culturepositive Yersinia enterocolitica infection. Gastroenterology 1987;92:112-7.

69. Freeman HJ, Weinstein WM, Shnitka TK, Piercey JRA, Wensel RH. Primary abdominal lymphoma: Presenting manifestation of celiac sprue or complicating dermatitis herpetiformis. Am J Med 1977;63:585-94.

70. Freeman HJ, Endelman AA, Forward AD, Quenville N. Diffuse multifocal small intestinal lymphoma presenting as a duodenal ulcer. Can Med Assoc J 1981:125:599-602.

71. Freeman HJ, Chiu BK. Small bowel malignant lymphoma complicating celiac sprue and the mesenteric lymph node cavitation syndrome. Gastroenterology 1986;90:2008-12.

72. Hourihane DOB, Weir DG. Malignant celiac syndrome. Report of two cases with malabsorption and microscopic foci of intestinal lymphoma. Gastroenterology 1970;59:130-9.

73. Schnitt SJ, Antonioli DA, Jaffe B, Peppercorn MA. Granulomatous inflammation of minor salivary gland ducts: A new oral manifestation of Crohn's disease. Hum Pathol 1987:18:405-7

74. Dudeney TP, Todd IP. Crohn's disease of the mouth. Proc Royal Soc Med 1969;62:1237-8

75. Bishop R, Brewster A, Antonioli D. Crohn's disease of the mouth. Gastroenterology 1972;63:302-6.

76. Carr D. Granulomatous cheilitis in Crohn's disease. Br Med J 1974:4:636.

77. Basu MK, Asquith P, Thompson RA, Cooke WT. Oral manifestations of Crohn's disease. Gut 1975; 16:249-54.

78. Scully C, Cochran KM, Russell RI, et al. Crohn's disease of the mouth: An indicator of intestinal involvement. Gut 1982;23:198-201.

79. Ward CS, Dunphy EP. Jagoe WS, Sheahan DG. Crohn's disease limited to mouth and anus. J Clin Gastroenterol
1985;7:516-21

80. Coenen C, Borsch G, Muller KM. Fabry H. Oral inflammatory changes as an initial manifestation of Crohn's disease antedating abdominal diagnosis. Dis Colon Rectum 1988;31:548-52.

81. Talbot T, Jewell E, Schloss E, Yakimets W, Thomson ABR. Cheilitis antedating Crohn's disease: Case report and literature update of oral lesions. J Clin Gastroenterol 1984;6:349-54.

82. Van Dyke TE, Dowell VR, Offenbacher S, Snyder W, Hersh T. Potential role of microorganisms isolated from periodontal lesions in the pathogenesis of inflammatory bowel disease. Infect Immun 1986;53:671-7.

83. Franklin RH, Taylor S. Nonspecific granulomatous (regional) esophagitis. J Thorac Cardiovasc Surg 1950;19:292-7.

84. Heffernon EW, Kepkay PH. Segmental esophagitis, gastritis and enteritis. Gastroenterology 1954:26:83-8.

85. Achenbach M, Lynch JP, Dwight RW. Idiopathic ulcerative esophagitis. Report of a case. N Engl J Med 1956;255:456-9.

86. Gelfand MD, Krone CL. Dysphagia and esophageal ulceration in Crohn's disease. Gastroenterology 1968;55:510-4

87. Dyer NH, Cook PO, Kemp Harper RA. Esophageal stricture associated with Crohn's disease. Gut 1969:10:549-54.

88. Miller LJ, Thistle JL, Payne WS, Gaffey TA, O'Duffy JD. Crohn's disease involving the esophagus and colon. Case report. Mayo Clin Proc 1977:52:35-8.

89. Lee CS, Mangla JC, Lee SSC. Crohn's disease in Barrett's esophagus. Am J Gastroenterol 1978;69:646-54

90. Freedman PG, Dieterich DT, Balthazar EJ. Crohn's disease of the esophagus. Case report and review of the literature. Am J Gastroenterol 1984:79:835-8.

91. Geboes K, Janssens J, Rutgeerts P, Vantrappen G. Crohn's disease of the esophagus. J Clin Gastroenterol 1986;8:31-7.

92. Rowe PH, Taylor PR, Sladen GE, Owen WJ. Cricopharyngeal Crohn's disease. Postgrad Med J 1987;63:1101-2.

93. Croft CB, Wilkinson AR. Ulceration of the mouth, pharynx and larynx in Crohn's disease of the intestine. Br J Surg 1972;59:249-52.

94. Bienenstock J. The physiology of the local immune response and the gastrointestinal tract. Progr Immunol 1974:4:197-207

95. Kelly JH, Montgomery WW, Goodman ML, Mulvaney TJ. Upper airway obstruction associated with regional enteritis. Ann Otol Rhinol Laryngol 1979;88:95-9.

96. Wilder WM, Slagle GW, Hand AM, Watkins WJ. Crohn's disease of the epiglottis, aryepiglottic folds, anus 
and rectum. J Clin Gastroenterol 1980;2:87-91.

97. Lemann M, Messing B, F'Agay F, Modigliani R. Crohn's disease with respiratory tract involvement. Gut 1987;28:1669-72.

98. Kraft SC, Earle RH, Roesler M, Esterly JR. Unexplained bronchopulmonary disease with inflammatory bowel disease. Arch Intern Med 1976; 136:454-9.

99. Chapin LF, Scudamore HH, Baggenstoss $\mathrm{AH}$, Bargen JA. Regional enteritis. Associated visceral changes. Gastroenterology 1965;30:404-15.

100. Shah SM, Texter EC, White HJ. Inflammatory bowel disease associated with granulomatous lung disease: Report of a case with endoscopic findings. Gastrointest Endosc 1976; 23:98-9.

101. Jones ER, Malone DNS. Sulfasalazine induced lung disease. Thorax 1972;27: 713-7.

102. Davies D, MacFarlane A. Fibrosing alveolitis and treatment with sulphasalazine. Gut 1974:15:185-8.

103. Thomas P, Seaton A, Edwards J. Respiratory disease due to sulfasalazine.
Clin Allergy 1974:4:41-7.

104. Williams T, Eidus L, Thomas P. Fibrosing alveolitis, bronchiolitis obliterans and sulfasalazine therapy. Chest 1982;81:766-8.

105. Yaffe BH, Korelitz BI. Sulfasalazine pneumonitis. Am J Gastroenterol 1983: 78:493-4

106. Johnson NM, Mee AS, Jewell DP, Clarke SW. Pulmonary function in inflammatory bowel disease. Digestion 1978; 18:416-8.

107. Pasquis P, Colin R, Denis P, Baptiste P, Galmiche JP, Hecketsweiler P. Transient pulmonary impairment during attacks of Crohn's disease. Respiration 1981:41:56-9.

108. Heatley RV. Thomas P. Prokipchuk E], Gauldie J, Sieniewicz DJ, Bienenstock J. Pulmonary function abnormalities in patients with inflammatory bowel disease. QJ Med 1982:51:241-50.

109. Bonniere P, Wallaert B, Cortot A, et al. Latent pulmonary involvement in Crohn's disease: Biological, functional, bronchoalveolar lavage and scintigraphic studies. Gut 1986; 27:919-25

110. Priebe WM, Simon JB. Crohn's disease of the stomach with outlet obstruction A case report and review of therapy. J Clin Gastroenterol 1983;5:441-5.

111. Woolfson K, Greenberg GR.

Symptomatic improvement of gastroduodenal Crohn's disease with omeprazole, Gastroenterology 1989; 96:A551.

112. Grill BB, Lange R, Markovitz R, Hillemeier AC, McCallum RW, Gryboski JD. Delayed gastric emptying in children with Crohn's disease. J Clin Gastroenterol 1985;7:216-26.

113. Harary AM, Gluck CA, Rogers AI. Gastric retention of enteric-coated sulfasalazine tablets. A complication of gastroduodenal Crohn's disease. Dig Dis Sci 1984;29:1063-5.

114. Williams CN. Additional comments on inflammatory bowel disease. Can Med Assoc J 1989;141:124.

115. Ross TM, Fazio VW, Farmer RG. Long term results of surgical treatment for Crohn's disease of the duodenum. Ann Surg 1983;197:399-406.

116. Lossing A, Lange B, Jeejeebhoy KN. Gastroduodenal Crohn's disease: Diagnosis and selection of treatment. Can J Surg 1983;26:358-60. 


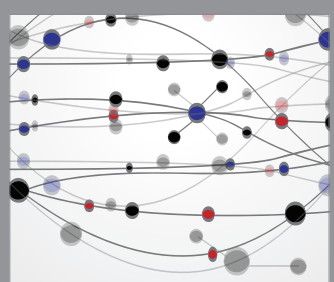

The Scientific World Journal
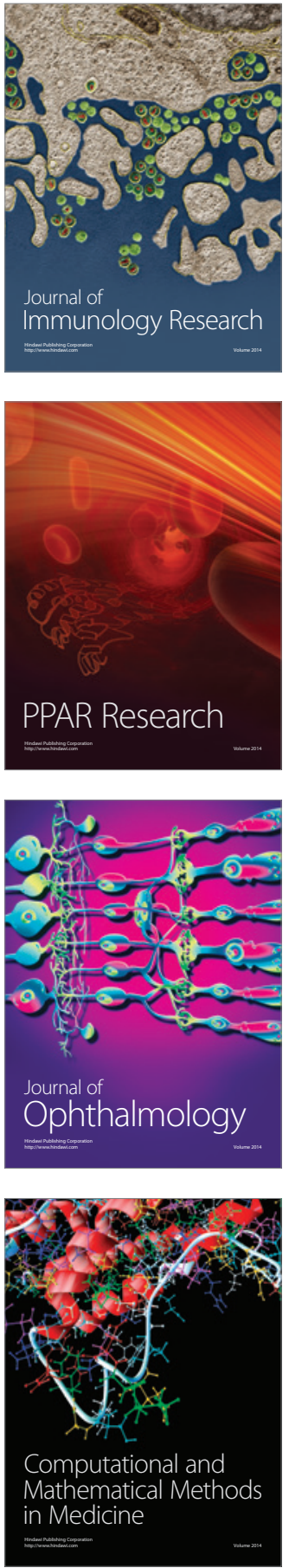

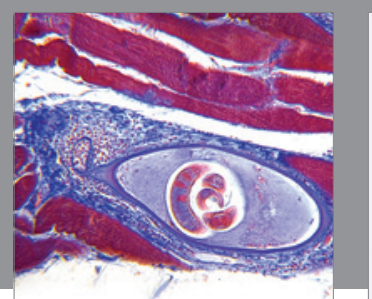

Gastroenterology Research and Practice

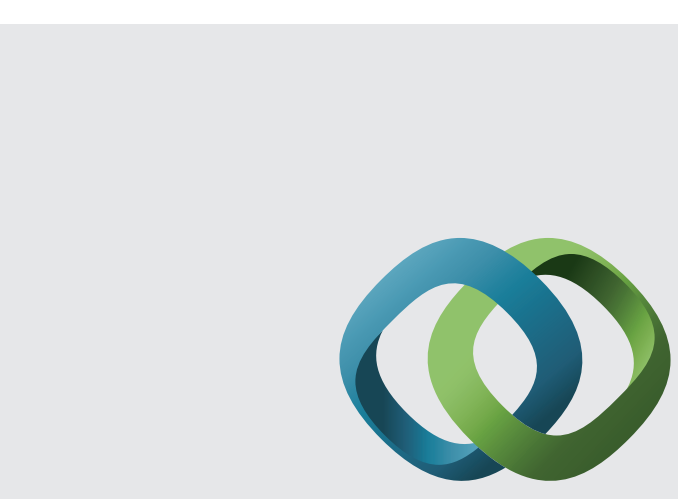

\section{Hindawi}

Submit your manuscripts at

http://www.hindawi.com
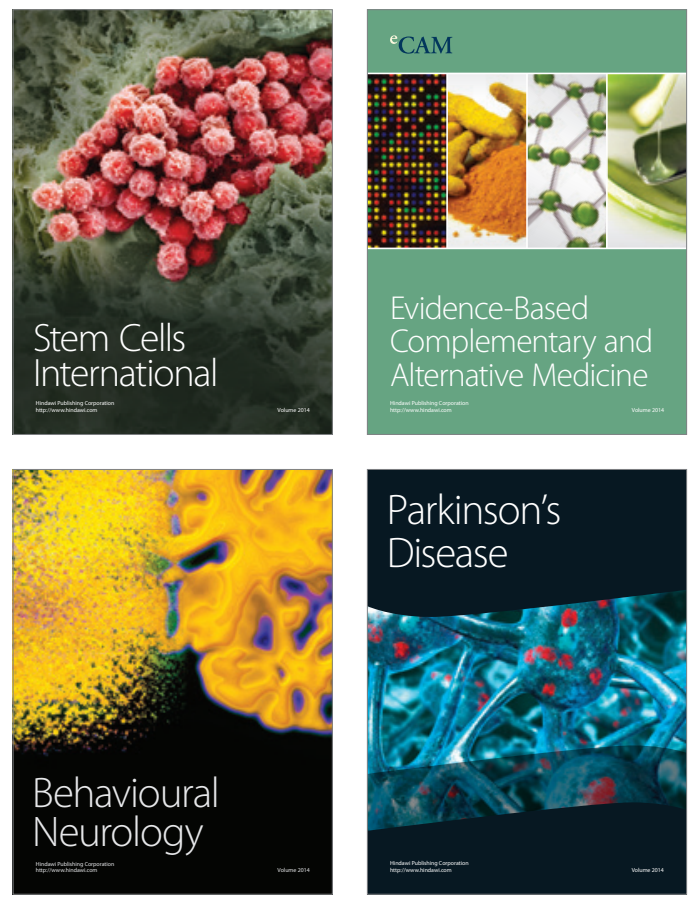
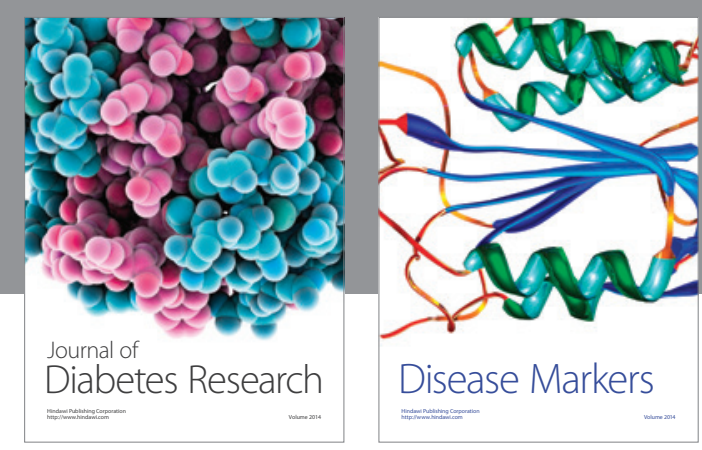

Disease Markers
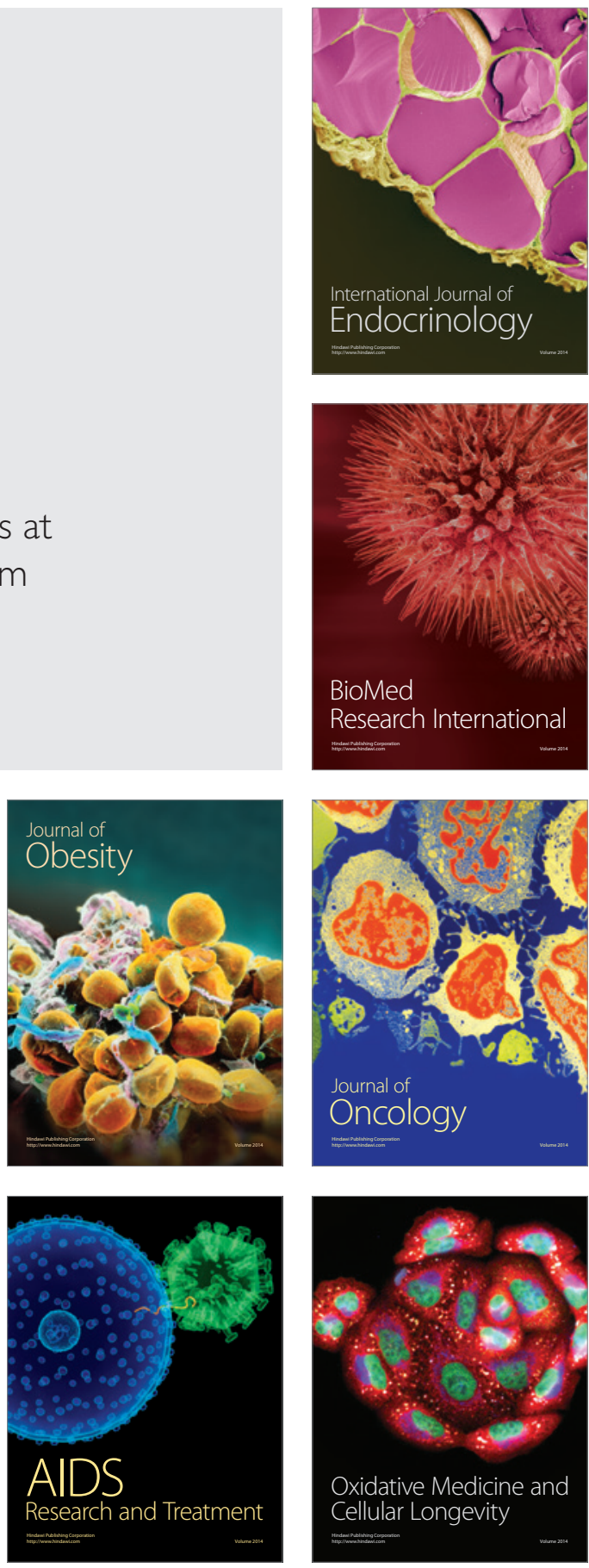